\title{
Roles of soil biota and biodiversity in soil environment - A concise communication
}

\author{
Suleiman Usman a*, Yakubu Muhammad b, Alhaji Maigana Chiroman c \\ a Department of Soil Science, Faculty of Agriculture, Federal University Dutse (FUD), Jigawa State, Nigeria \\ b Department of Soil Science, IBB University of Science and Technology, Lapai, Niger State, Nigeria \\ c Department of Soil Science, University of Maiduguri (Unimaid), Borno State Nigeria
}

\section{Article Info}

Received : 09.12.2015

Accepted : 08.03.2016

\begin{abstract}
Soil biota (the living organisms in soil) plays an important role in soil development and soil formation. They are the most important component of soil organic matter decomposition and behave efficiently in the development and formation of soil structure and soil aggregate. Their biodiversity provides many functional services to soil and soil components. They help in dissolving verities of plant and animal materials, which could left as decayed organic matter at the surface soil. Understanding the vital role of soil organisms would undoubtedly helps to increase food production and reduces poverty, hunger and malnutrition. Soil biota and biodiversity research in subSaharan Africa would play an important role in sustaining food security, environmental health, water quality and forest regeneration. This paper, briefly highlighted some of the biological functions of soil biota and suggests that proper understandings of biota and their biodiversity in soil environment would provide ways to get better understanding of soil health, soil function, soil quality and soil fertility under sustainable soil management activities in agricultural production.
\end{abstract}

Keywords: Soil biota, biodiversity, soil environment.

\section{Introduction}

Soils and soil environmental studies require awareness about the immediate environment within the magnitude of the biological organisms' presence (Ritz et al., 2010). These studies may include the subject themes relevant to soil science and its components, crop science and sustainable economic developments, animal science and its husbandries, forestry and forest managements, fishery and its managements as well as environmental risk assessment. Therefore, knowledge of biological organisms is needed in many aspects of agricultural and environmental assessments (De Bello et al., 2010). Lack of access to this knowledge is a clear determinant of limited sound knowledge on what our global ecosystem is all about, and also a scientific challenge for new agricultural developments (Brussaard et al., 2010). These organisms or soil biota include the bacteria, actinomycetes, fungi and algae (the micro-flora); the protozoa and nematode (the micro-fauna); the collembolan, mites, termites, ants and other associated micro-organisms and meso-fauna and flora (Usman, 2013). They play a vital role in the soil and represent large function of global biodiversity and global ecosystem (FAO, 2005; Petchey and Gaston, 2006). Thus, providing a better understanding of the linkages

\footnotetext{
${ }^{*}$ Corresponding author.

Department of Soil Science, Faculty of Agriculture, Federal University Dutse (FUD), Jigawa State PMB 7156 Nigeria

Tel.: +2347034233241

E-mail address: labboallugu@yahoo.com

e-ISSN: $2147-4249$

DOI: 10.18393/ejss.2016.4.255-265
} 
between soil parent materials, plant community composition, forest regeneration, organic matter and diverse organisms in wider contrasting environments (Eskelinen et al., 2009; Loreau, 2010).

Generally, without vital recycling processes of soil organisms, the soil would become a stockpile of dead plant and animal materials with no facilities to reprocess essential nutrients such as carbon, nitrogen and phosphorus in soil ecosystem (Eskelinen et al., 2009). Thus, the conditions and maintenance of soil environment together with proper understanding of soil biota and their biodiversity are central to the role played by various microorganisms that live in agricultural soil environment (Brussaard et al., 2007). The role of these organisms in soil formation and development has been well documented (Jenny, 2009). However, their activities in soil environment and soil ecosystem functions have been considered the most important component of nutrient recycling and soil quality managements (Kramer and Gleixner, 2008; Culman et al., 2010; Usman, 2013). This indicates that the role of soil microbial community requires a vast understanding and an expanding study into proper appreciation of many aspects of soil environment. Therefore, the objectives of this paper are to provide a concise elucidation of the roles of soil biota and their biodiversity in the global soil development and soil transformation.

\section{Soil biota and biodiversity - a way forward}

From the perspective of soil scientists, soil biota is a general term refers to all soil organisms living and communicating in soil environment. Ritz et al. (2004) considered soil biota as the 'biological engine of the earth', - driving and transforming physical, chemical, biological and ecological processes in global soils. Soil biota are described as micro-, macro- and meso-biota. Bacteria and fungi are the major group of micro-biota and exist in numerous number in agricultural soil and grassland areas (Riesenfeld et al., 2004; De Vries et al., 2006). Their ranges were identified as the smallest in different sizes, extremely abundant and diverse, and able to decompose almost any existing natural material in soil (Figure 1).

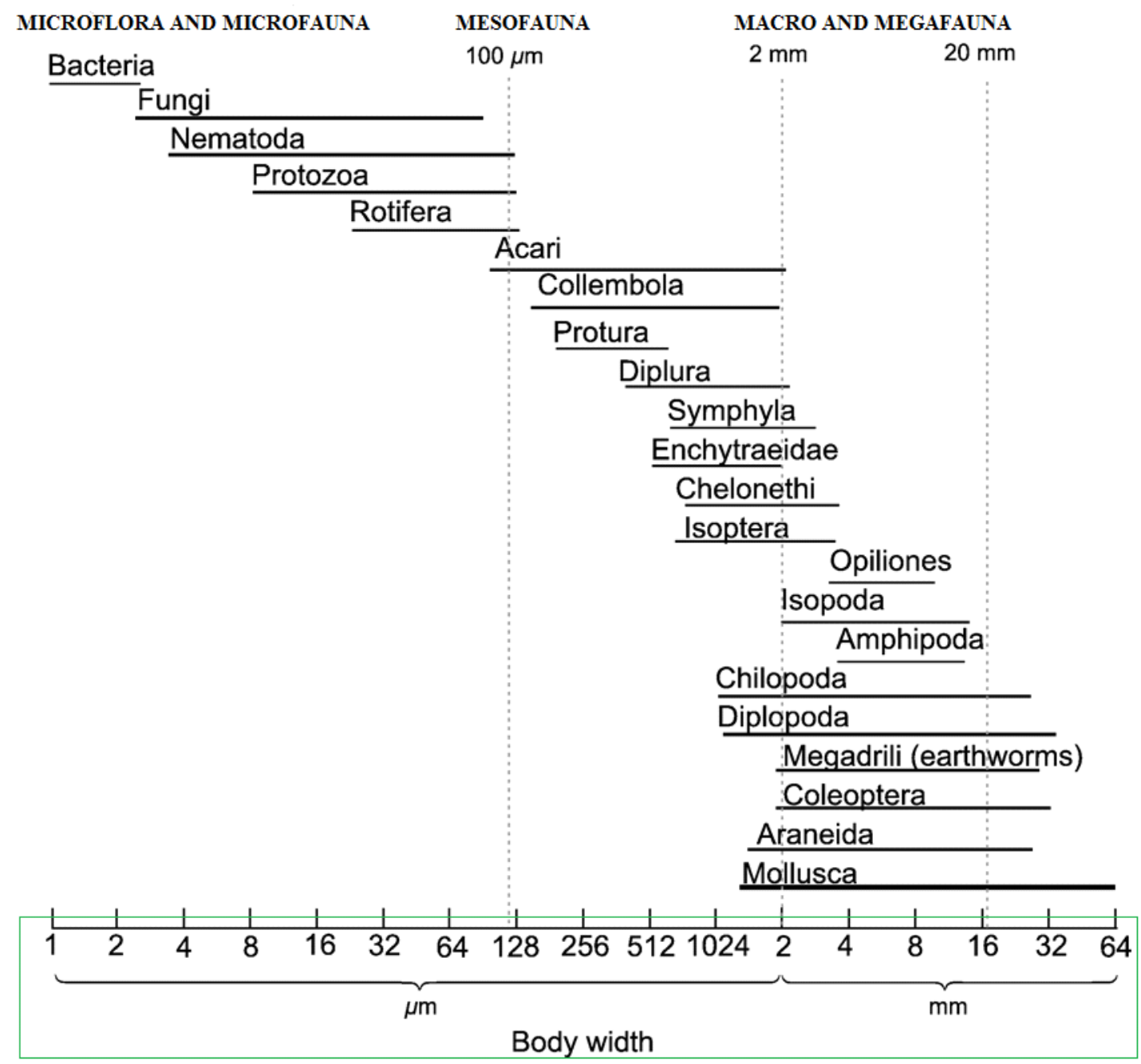

Figure 1. Size classification of soil organisms according to body width (Adapted and modified after Swift et al., 1979) 
Soil macro and meso fauna are groups of biota that are also very important in soil medium. These organisms include the earthworms, termites, arthropods, millipeds, ants, moles, protozoa and nematodes (Coleman, 2001). They play a vital role in moving soil particles, transforming soil structure and enhancing soil moisture (Ritz et al., 2004). Earthworms are considered numerous and grouped into 23 families, 700 genera and many species (Usman, 2013). Termites are described as grass harvester, surface litter feeders, wood feeders and soil feeders 'humivores' (FAO, 2005); probably up to 10,000 species exist in soil medium (Coleman, 2001). Arthropods are grouped into Coleoptera which believe to cover $48 \%$ of the population followed by Acari and Formicidae species (FAO, 2005). Nematodes are considered the major consumers classified as bacteria feeders, fungal feeders, plant feeders, predators and omnivores (Usman, 2013). These groups of nematodes were identified to range between 0.15 to $5 \mathrm{~mm}$ long and 2 to $100 \mu \mathrm{m}$ wide (FAO, 2005). Also, about 40,000 species of soil protozoa have been described, with as many as 50 individuals in a single soil medium (Coleman, 2001). Generally, the sustainable function of natural and agricultural soil ecosystems is dependent on the contribution that these groups of biota and their biodiversity offer (Barrios, 2007). Table 1 describes an estimated number of species of these groups of biota according there body structure and sizes.

Table 1. Estimated number of species of plants and of soil organisms organized according to body size (After Wall et al., 2001)

$\begin{array}{cccc}\text { Size } & \text { Known species } & \text { Estimated total species } & \text { \% Known } \\ \text { Vascular plants } & & & \\ \text { Macrofauna } & 270.000 & 300.000 & 50 \\ \text { Ants } & 8.800 & 15.000 & 53.7 \\ \text { Termites } & 1.600 & 3.000 & \text { No estimate } \\ \text { Earthworms } & 3.600 & \text { No estimate } & 2.2-3.3 \\ \text { Mesofauna } & 20.000-30.000 & 900.000 & 27.1 \\ \text { Mites } & 6.500 & 24.000 & 7.5 \% \\ \text { Collembola } & 1.500 & 200.000 & 1.3 \\ \text { Microfauna } & 5.000 & 400.000 & 1 \% \\ \text { Protozoa } & 13.000 & 1.000 .000 & 1-2 \% \\ \text { Nematodes } & 18.000-35.000 & 1.500 .000 & \end{array}$

\footnotetext{
a Estimates for vascular plants (UNEP, 1995)
}

On the other hand, soil biodiversity is comprised of the organisms that spend all or a portion of their life cycles within the soil or on its immediate surface (Coleman, 2008). This reflects complexity and diversity of the species of living organisms in the soil (invisible microbes to visible macro-biota) (Wall et al., 2001). Thus, soil biota must be selectively studied because of their high diversity and wide distribution in the composite and heterogeneous soil medium at scales ranging from microns to meters (Barrios, 2007). This means that the biodiversity of soil biota is an industry with diverse components that worked together to transform the soils into lively and functional environment. And, as such make up the diversity of life that represents a large fraction of global terrestrial biodiversity in soil (Bardgett, 2005).

Soil biota interacts and communicates with each other forming a food web within soils (FAO, 2005). This interaction indicates how their activities are vital in providing many essential services to our global soil ecosystem (Table 2).

Table 2. Ecosystem services provided by soil biota (adapted after modifications made by Brussaard, 2012 from the work of Kibblewhite et al., 2008)

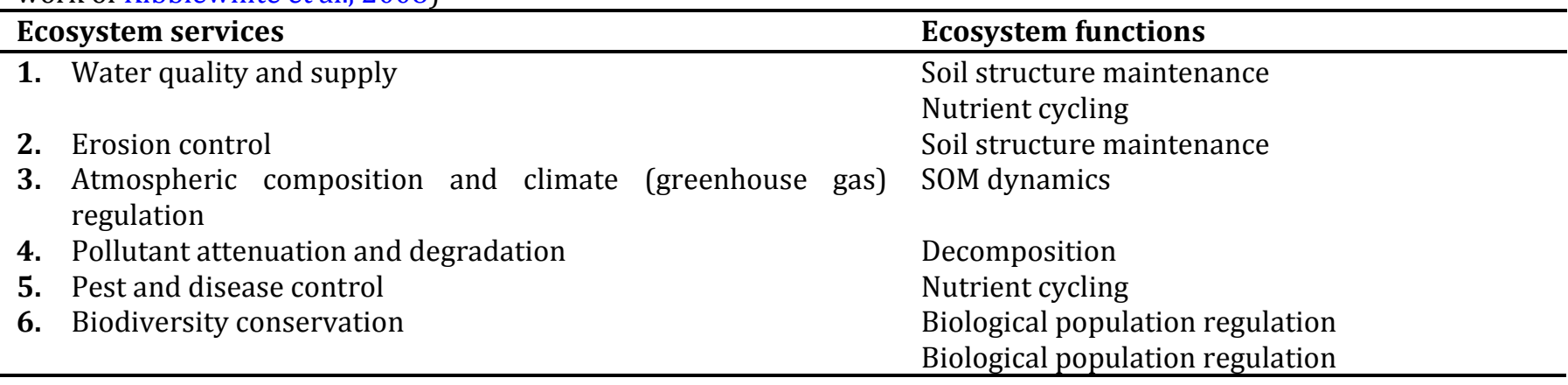




\section{Soil biota: functional and taxonomic concept}

Soil biota can be distinguished by considering their functional services and taxonomic classification. This concept is quite very important because of the need to note that not all the groups of biota are connected with agricultural soil functions. The $21^{\text {st }}$ Century technologies related to DNA sequences revealed that some members of soil biota have no direct or weak relationship with providing functional services to soil medium (Riesenfeld et al., 2004; Bardgett, 2005; Barrios, 2007). This effort helps soil biologists to expand their understanding into many aspects of soil biota, and also to determine how these organisms behave very well in soil environment (Coleman, 2008; Ritz et al., 2010; Castro-Huerta et al., 2015). Taxonomic soil biota provides a linkage to identify some species of soil organisms that are only presence in soil without much support to soil quality and soil management (Riesenfeld et al., 2004). These organisms could be silent when speaking about the role of biota in soil environment, because their biodiversity and contributions are very weak unlike with those organisms that have a very strong functional diversity (Petchey and Gaston, 2006).

\section{Soil biota: an environmental issues of the $21^{\text {st }}$ Century}

Environmental issues related to agricultural soils and food security are quite very important in determining and understanding the role of soil biota and their biodiversity (Wall et al., 2001). For example, agricultural soil management, environmental pollution, global warming, soil degradation and climate change are directly and indirectly connected with the existence and biodiversity of many soil organisms (de Bello et al., 2010). These environmental issues were considered the major threat to soil and its biological components including the biota and their biodiversity (UNEP, 2006). Their physical and chemical deteriorations have put agricultural production at stake while decline soil quality has affected many functional services of million soil organisms as well as their presence and existence/population in agricultural soils (Bai et al., 2008). This indicates the need of constant understanding of how these organisms behave and contribute to the global ecosystem development particularly in the aspect of agriculture or food security (Ritz et al., 2010).

\section{Role of soil biota in soil environment - a brief guide}

The science of soil biology has functionally linked the populations of soil organisms of all kinds, sizes and shapes through their roles in the decomposition of various forms of plants and animal materials (FAO, 2005). Thus, the roles played by soil biota were considered vital in transforming and improving soil properties and soil quality (Lupswayi et al., 1998; Miyazawa et al., 2000). These functions of soil biota were reported to create vital activities, which are considered to be part of biological indicators of soil health (Pankhurst et al., 1997; Kibblewhite et al., 2008). Coleman (2001) noted that the soil biota is responsible to a varying degree for performing vital functions in the soil. They contribute with a wide range of essential services to the sustainable function of all ecosystems, by acting as the primary driving agents of nutrient cycling, regulating the dynamics of soil organic matter, soil carbon sequestration and greenhouse gas emission; modifying soil physical structure and water regimes, enhancing the amount and efficiency of nutrient acquisition by the vegetation, enhancing plant health and maintain soil quality (Denef et al., 2001; FAO, 2005; Wang et al., 2008; Dominguez et al., 2014; Castro-Huerta et al., 2015). FAO (2007) provides a notable digest of the essential functions performed by soil biota in our global soil environment (Table 3).

Table 3. Summarized key roles of soil biota in soil environment (After FAO, 2007)

\begin{tabular}{|c|c|c|}
\hline & Role of soil biota & Key organisms involved (examples) \\
\hline 1. & Maintenance of soil structure & $\begin{array}{l}\text { Earthworms, arthropods, soil born fungi, mycorrihizas, plant } \\
\text { roots }\end{array}$ \\
\hline 2. & Regulation of soil hydrological processes & Mostly micro-organisms and plant roots \\
\hline 3. & Gas exchange and carbon sequestration & Mostly micro-organisms \\
\hline 4. & Soil detoxification & Various saparophytic, bacteria, fungi etc \\
\hline 5. & Decomposition of organic matter & $\begin{array}{l}\text { Mycorrhizas and other fungi, nematodes, bacteria, earthworms, } \\
\text { termites }\end{array}$ \\
\hline 6. & Suppression of pests and diseases & Varieties of fungi and bacteria \\
\hline 7. & Sources of food and medicine & Plant roots, stems and leaves; various insects, earthworms \\
\hline 8. & $\begin{array}{l}\text { Symbiotic and asymbiotic relationship with } \\
\text { plants and their roots }\end{array}$ & Rhizobia, mycorrhizae, actinomycetes \\
\hline 9. & Plant growth control (positive + negative) & $\begin{array}{l}\text { Direct effects e.g. plant roots, actinomycetes, rhizobia, } \\
\text { mycorizas; indirect: most soil biota }\end{array}$ \\
\hline
\end{tabular}




\section{Physical and biological component of soil medium}

Soil organisms provide many supports in the trasformation and development of soil physical and biological properties. They are exclusively part of soil formation and decomposition processes of diverse plant and animal materials (Janney, 1994). Bacteria contribute to the carbon cycle by fixation (photosynthesis) and decomposition of organic materials and hence might improve soil colour and soil quality (Darbyshire, 1994; FAO, 2005). Their activities might also help to improve the strength of soil particles and soil resilience against soil runoff and soil erosion. Fungi also help in binding soil particles and an increase water infiltration and soil water holding capacity (Alfred, 2001; Ritz et al., 2004). Generally, a ton of microscopic bacteria may be active in each acre of soil as typically indicated in Figure 2 (NRCS: www.nrcs.usda.gov720 × 475 Search by image). These active organisms fall into four functional groups - decomposers, mutualists (form partnership with plants - nitrogen-fixing bacteria), pathogens and lithotrophs or chemoautotrophs; both played a vital role in soil nutrient cycling (Coleman et al., 1983; Ingham, 2000).

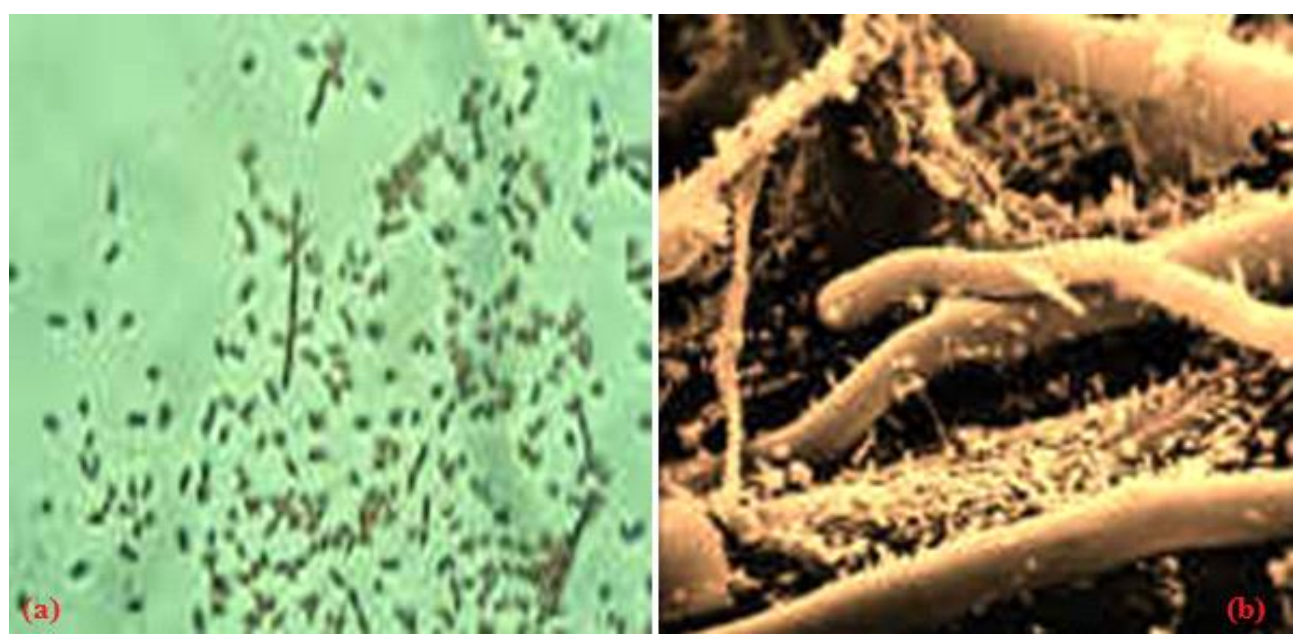

Figure 2. Microscopic representation of bacteria biodiversity in soil environment: (a) a ton of microscopic bacteria may be active in each acre of soil and (b) Bacteria dot the surface of strands of fungal hyphae [The images were used by the authors with the copyright permission of Soil and Water Conservation Society]

Earthworms play a significant role in regulating soil physical and chemical properties and soil processes (Lubbers et al., 2011). Earthworms are the major decomposers of dead organic matter and transformed soil structure, aggregate particles, soil colour and surface soil layers (Edward, 2000).Earthworms are very mobile organisms, which substantially create, inhabit, and burrow the soil particles for quite advance soil developments (Smith et al., 2008). Jongmans et al. (2003) noted that earthworms essentially change soil structure by casting and burrowing and as such improve soil aggregate stability, cohesion and adhesion in soil and pore-size division.

Another soil biota in this consideration is protozoa. These organisms move soil particles and help in the decomposition processes of soil organic matter (Corliss and Esser, 1974; Darbyshire, 1994; Song et al., 2004). Yeates and Coleman (1982) recognized nematodes in soils environment. These flexible organisms play an important role in soil health, soil function, and soil organic matter decomposition processes (Coleman et al., 1984; Bardgett, 2005; Kramer and Gleixner, 2008). Termites played an important role in modifying the soil particles into fine and stable aggregate. Termites sustain other components of soil biota in soil, and increase soil water infiltration rate (Allen, 1990). Termites are divided into three groups according to the structure of their nests (those that build mounds) (FAO, 2005): (a) above ground, (b) on the soil surface, and (c) below ground. The most notable role of these termites in soil environment is depicted in Figure 3.

\section{Chemical and management component of soil medium}

Soil organisms were considered the most important component of soil that help in the proper cyclation of nutrients availability in soil (Coleman et al., 1984; Ritz et al., 2010). Soil biota such as plants are also considered the major producers, which used solar energy to fix carbon from carbon dioxide through photosynthesis, and help to produce roots, tubers and other underground organs within soil body (Fageria et al., 2002). These plant organs have a great influence on soil properties and soil formations (Fageria et al., 2002; Dominguez et al., 2014). The root plays an important function in binding soil particles and resilience 
against soil erosion and unacceptable environmental changes (Castro-Huerta et al., 2015). The leaves and litter materials from the trees also add organic matter to the soils (Li et al., 2014). Overall (FAO: www.fao.org/biodiversity): soil biota and their biodiversity play a role in soil fertility, soil rehabilitation and nutrient uptake by plants, biodegradation processes, reducing hazardous waste and control of pests through natural biocontrol; enhance crop productivity through recycling the basic nutrients required for all ecosystems (nitrogen, phosphorus, potassium and calcium), breaking down organic matter into humus, increasing soil porosity and water infiltration.
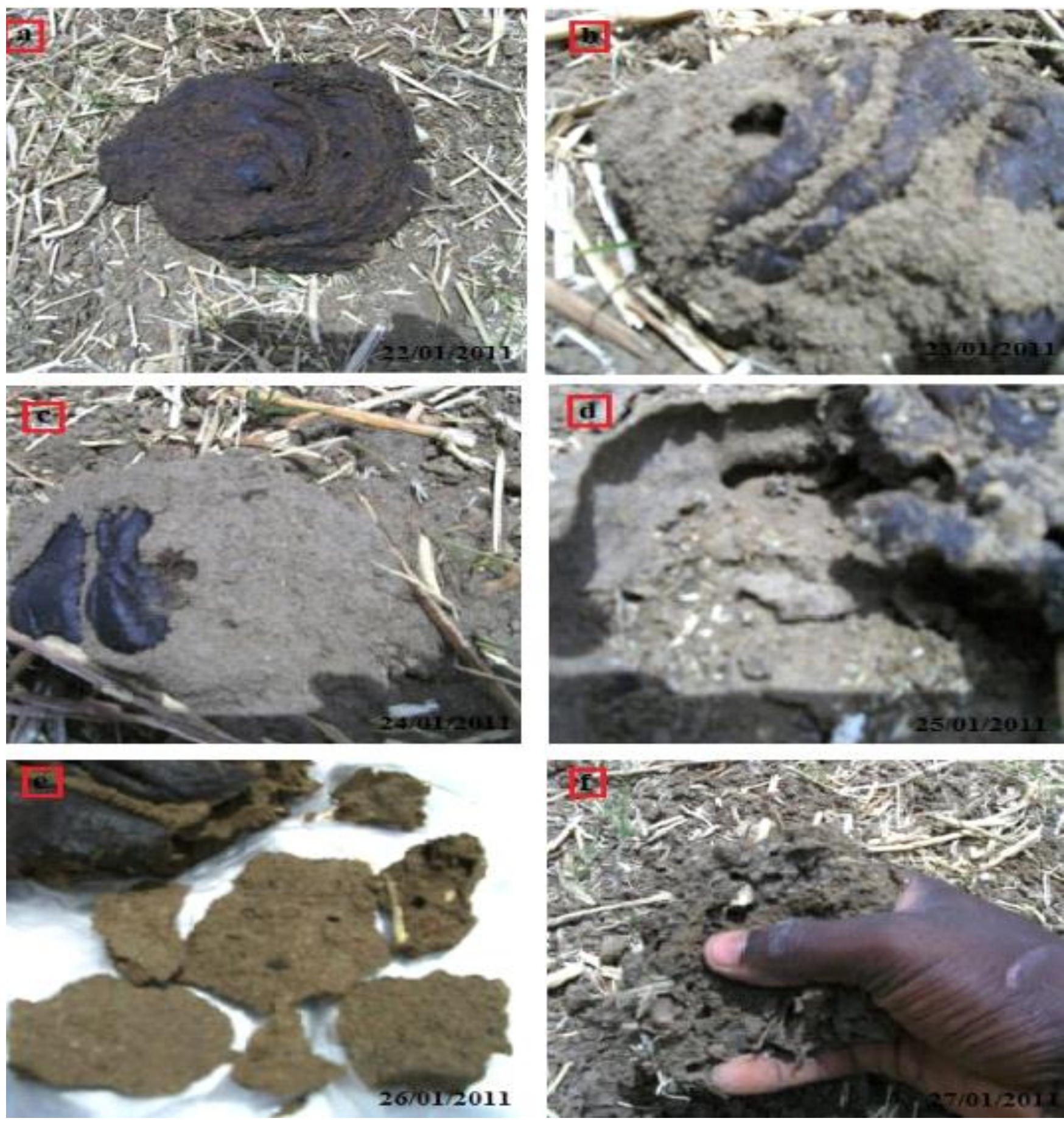

Figure 3. Typical example of physiological function of soil biota (termites) in soil environment within 6 consecutive days: (a) cow dung dropped by a cow under cattle rearing, (b) decomposition process begins after one day, (c) transformation of organic compound from complex to simple form in day 3, (d) simple organic particles are trying to become part of soil body in day 4, (e) stable aggregate soil particles in plate-like structure are produced in day 5 and (f) organic compounds completely become part of soil body produced well-granules particles in day 6 . Photos by Suleiman 


\section{Physiological interactions with soil aggregates}

As clearly observed by Tisdall and Oades (1982), our understanding of soil biota and their role in soil environment could be transiting from analogue stage to digital level. Soil organic matter which is the vital component of soil quality development in soil environment undergoes some important decomposition processes (mineralization and humification). Mineralization is a biochemical breakdown of organic materials by soil biota whereas humification is the change of simple organic substances into larger molecules, which finally become humus (FAO, 2005). However, in the model of aggregate organization as depicted in Figure 4, it is very clear that soil biota participate fully in aggregate formation and developments. They bind soil particle together, improve the stability and cohesion of aggregate development and help in nutrients cycling within the pores of different sizes (Six et al., 2004).
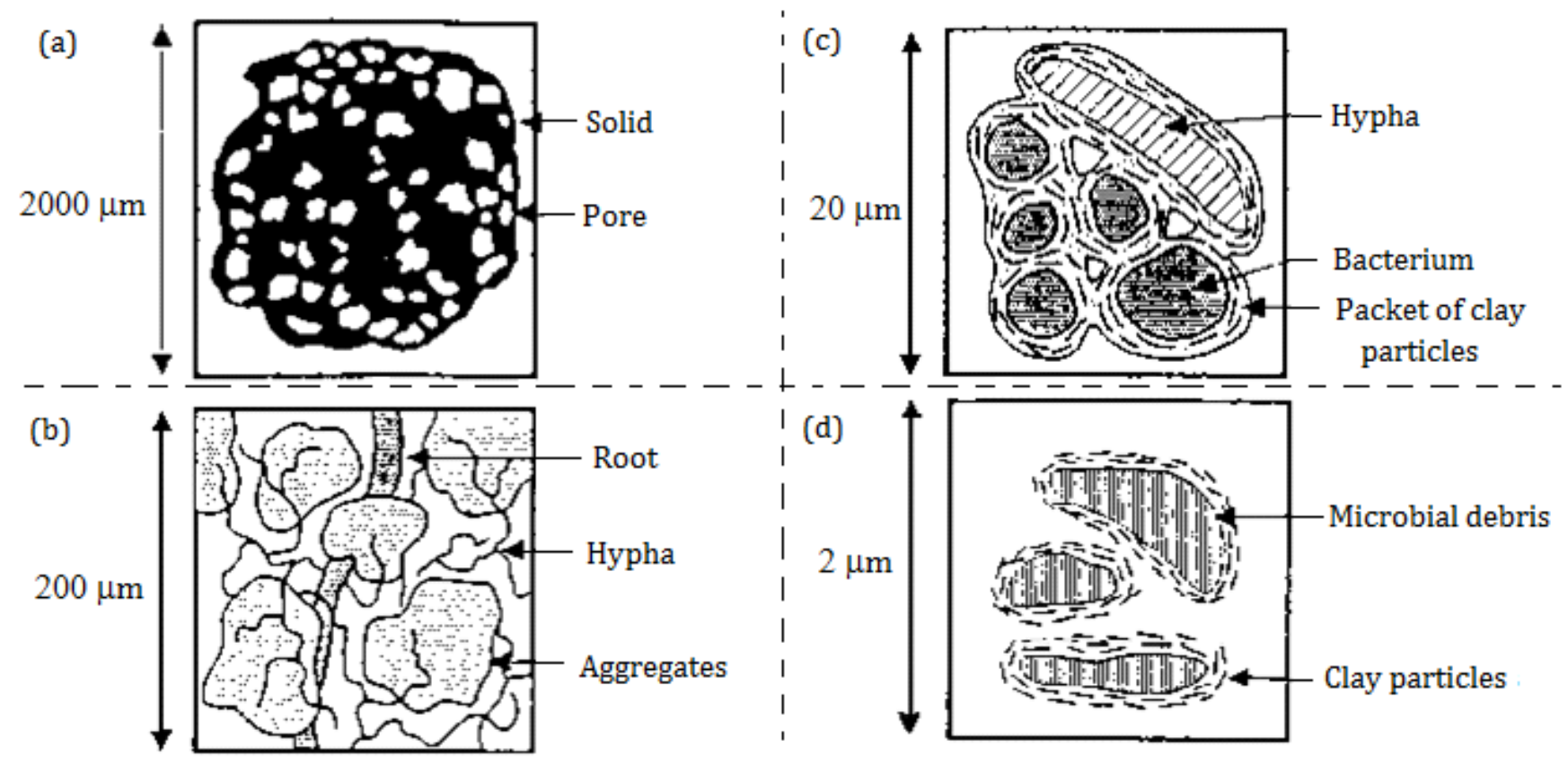

Figure 4. Model of aggregate organization with major binding agents indicated (a) Solid pore (b) Roots and hyphae (medium-term organic), (c) Plant and fungal debris encrusted with inorganics (persistent organic) and (d) Microbial and fungal debris encrusted with inorganics (persistent organic) (After Tisdall and Oades 1982)

FAO (2005) noted that numerous microbes exist in soil particles and or within the surface areas of soil micro-aggregates. Thus, soil micro-aggregates could be considered as zoological houses where millions of bacteria and fungi occupied. Riesenfeld and co-workers noted that one gram of soil may contain thousands of species and billions of individual soil microorganisms (Riesenfeld et al., 2004). Their presence provides many essential ecosystem services to soil aggregates and soil structures (Table 4).

Soil biota also makes soil to become added lively for great diversity of numerous bacteria and fungi in soil environment (Rillig and Mummey, 2006). Similarly, the arrangement of soil particles into different shapes, sizes and forms are vital to the soil formation and soil development (Jenney, 2009). Indeed, soil biota played a vital role in this process. Ritz et al. (2010) noted that soil biota produce soil structure by a number of direct and indirect processes. These processes are (Ritz et al., 2010):

a. Moving and aligning primary particles along cell or hyphal surfaces;

b. Adhering particles together by the action of adhesives involved in colony cohesion, and other exudates, such as extra-cellular polysaccharides (EPS);

c. Enmeshment and binding of aggregates by fungal hyphae and actinomycete filaments, and associated mycelia;

d. Coating pore walls with hydrophobic compounds, particularly by fungi which produce such polymers to insulate their mycelia, which have a relatively large surface area: volume ratio. 
Table 4. Functional services of soil biota to soil aggregate particles (adapted after modifications made by Brussaard, 2012 from the work of Kibblewhite et al. 2008)

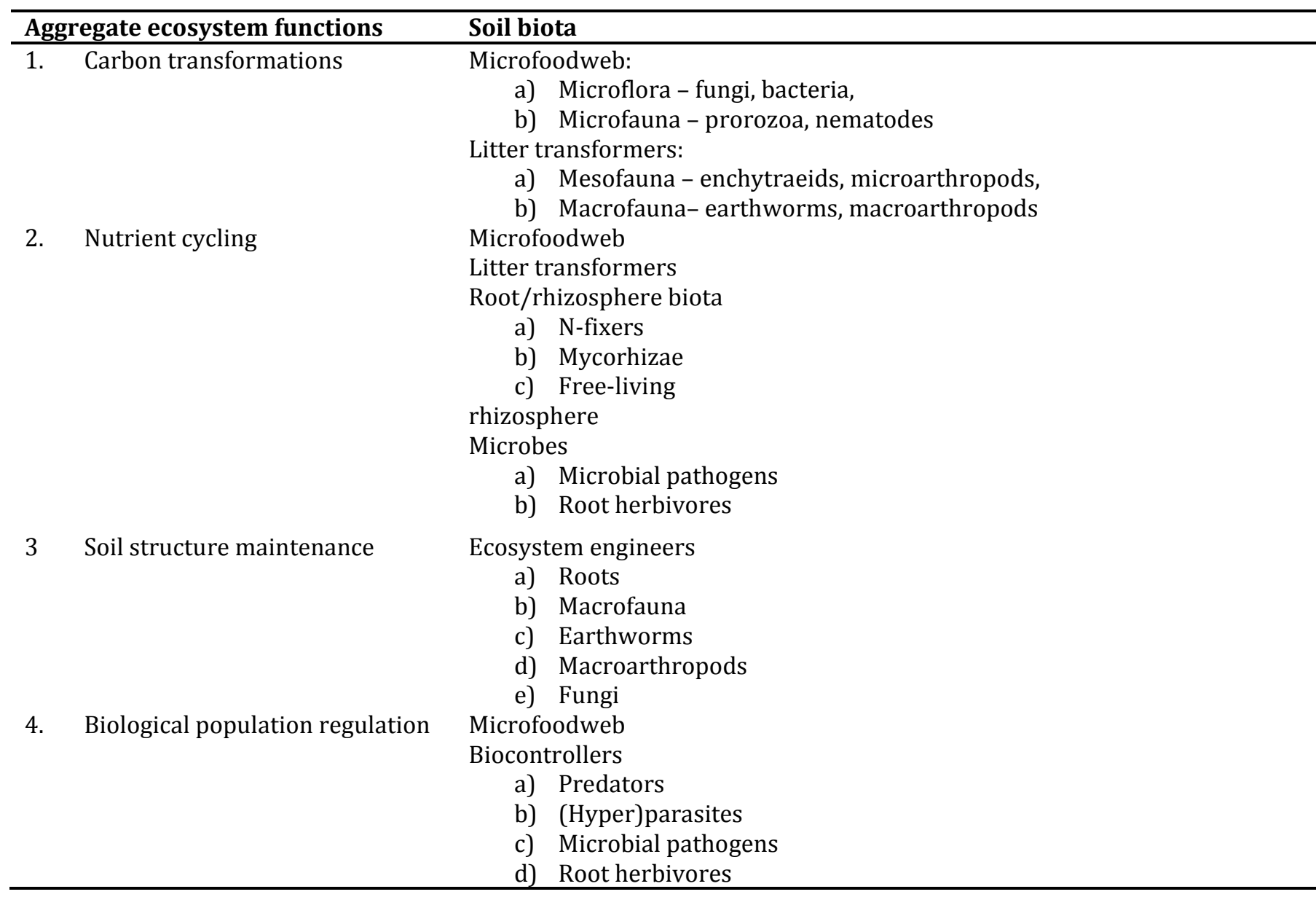

\section{Gaps and challenges: - sub-Saharan African context}

There have been many researches carried out regarding the soil microbial communities, globally. To date, majority of these researches were based in Europe, US, UK and in China (e.g. Colleman et al., 1983; De Vries et al., 2006; Brussaard et al., 2007; Wang et al., 2008; Eskelinen et al., 2009; Ritz et al., 2010; Li et al., 2014; Castro-Huerta et al., 2015). Similarly, there are also some important researches carried out in Africa on biota and biodiversity of which Jürgens et al. (2012) provided important information on their patterns at different spatial scales, which fill gaps of critical baseline information that are missing in the region. Nonetheless, researches on soil biota and biodiversity in sub-Saharan Africa are still need to be expanded into many aspects of soil and agricultural production, environmental conservation, climate change and land degradation; because soil biota and biodiversity were considered the root of sustainable agriculture in the $21^{\text {st }}$ century (FAO, 2007). Therefore, achieving sustainable agriculture in sub-Saharan Africa must focus on food security within its boundaries, and as such, we do believe that there must be an engagement into aspect of soil research relevant to biota and biodiversity in the region. Although, this may be a challenge due to poor research and development, findings and government contributions; however, we are of the opinion that academic environments in the region may have the role to play in future. They need to develop and create an environment that would provide opportunity for undergraduate and post-graduate students to fully involve into different components of soil microbial studies to fill the gaps that are missing.

\section{Conclusion}

Soil biota or soil organisms are important component of soil environment and play important roles in transforming soil in varying forms. The role of soil biota is vital to soil properties and soil components. They breakdown soil particles for soil quality and soil function. Their leaves, stems and other surface organs play an important role in maintaining soil properties and improving soil organic matter. Plant debris and organic compounds in soil are largely decomposed and transformed by soil biota. They influence the stabilization and destabilization of soil organic materials for soil quality and soil fertility development. Proper 
understandings of soil biota and their biodiversity in soil environment would provide ways to improve soil health, soil function, soil quality, soil fertility and sustainable soil management activities in agricultural production.

The campaign to engage into the research on soil biota and biodiversity in sub-Saharan Africa will require long-term effort, and the benefits will be seen in the development of soil quality and soil fertility within a short-term course. From our mini-review of the role of soil biota here we do not have much confidence that many countries in the region are in a better commitments to fully support researches in the subject matter. However, it is significant to emphasise the needs to further expand our understanding into many aspects of soil organisms and their roles in relation to sustainable agriculture, environmental pollution, global warming, and climate change and food security. And, to target a specific research area particularly in the aspect of taxonomic soil biota, one must first understand the soil organisms' involved and the way in which they are distributed/behaved in soil medium. Also, while both the field and laboratory data requirements are quite important, we have shown that assessments and analyses are possible in the aspects of physical, chemical and biological relationships between soil biota and the role they played in soil medium. Thus, establishing a very useful approach to achieve the outline objectives could be possible under any given research subject related to the work on soil biota and biodiversity.

\section{References}

Alfred, R. C. Jr., 2001. Soil micro-organisms In: Soil sediment and water: The magazine of environmental assessment and remediation. The Association of Environmental Health and Science (AEHS): Amherst, USA.

Allen, J.J., 1990. Termites, soil fertility and carbon cycling in dry tropical Africa: A hypothesis. Journal of Tropical Ecology 6 (3): 291-305.

Bai, Z.G., Dent, D.L., Olsson, L., Schaepman, M.E., 2008. Proxy global assessment of land degradation. Soil Use Management 24: 223 - 234.

Bardgett, R.D., 2005. The biology of soil: A community and ecosystem approach. Oxford University Press, Oxford, New York. $242 \mathrm{p}$.

Barrios, E., 2007. Soil biota, ecosystem services and land productivity. Ecological Economics 64(2): 269-285.

Brussaard, L., 2012. Ecosystem services provided by the soil biota. In: Soil ecology and ecosystem services. Wall, D.H., Bardgett, R.D., Behan-Pelletier, V., Herrick, J.E., Jones, T.H., Ritz, K., Six, J., Strong, D.R., van der Putten, W.H. (Eds). Oxford University Press. pp.45-58.

Brussaard, L., Caron, P., Campbell, B., Lipper, L., Mainka, S., Rabbinge, R., Babin, D., Pulleman, M., 2010. Reconciling biodiversity conservation and food security: scientific challenges for a new agriculture. Current Opinion in Environmental Sustainability 2(1-2): 34-42.

Brussaard, L., de Ruiter, P.C., Brown, G.G., 2007. Soil biodiversity for agricultural sustainability. Agriculture, Ecosystems and Environment 121(3): 233-44.

Castro-Huerta, R.A., Falco, L.B., Sandler, R.V., Coviella, C.E., 2015. Differential contribution of soil biota groups to plant litter decomposition as mediated by soil use. PeerJ 3:e826.

Coleman, D. C., 2001. Soil biota, soil systems, and processes. In: Encyclopaedia of Biodiversity. Levin, S.A. (Ed).Vol. 5, Academic Press. pp.305-214.

Coleman, D. C., 2008. From peds to paradoxes: Linkages between soil biota and their influences on ecological processes. Soil Biology and Biochemistry 40(2): 271-289.

Coleman, D.C., Ingham, R.E., McClellan, J.E., Trofymow, J.A., 1984. Soil nutrient transformations in the rhizosphere via animal-microbial interactions. In: Invertebrate Microbial Interactions. Anderson, J.M., Rayner, A.D.M., Walton, D.C.M. (Eds.). Cambridge University Press, pp. 35-58.

Coleman, D.C., Reid, C.P.P., Cole, C.V., 1983. Biological strategies of nutrient cycling in soil systems. Advances in Ecological Research 13: 1-55.

Corliss, J.O., Esser, S.C., 1974. Comments on the role of the cyst in the life cycle and survival of free-living protozoa. Transactions of the American Microscopial Society 93(4): 578-593.

Culman, S.W., Young-Mathews, A., Hollander, A.D., Ferris, H., Sánchez-Moreno, S., O’Geen, A.T., Jackson, L.E., 2010. Biodiversity is associated with indicators of soil ecosystem functions over a landscape gradient of agricultural intensification. Landscape Ecology 25(9): 1333-1348.

Darbyshire, J. F., 1994. Soil Protozoa. CABI Publishing, Wallingford, UK. 209 pp.

de Bello, F., Lavorel, S., Díaz, S., Harrington, R., Cornelissen, J.H.C., Bardgett R,D., Berg, M.P., Cipriotti, P., Feld, C.K., Hering, D., da Silva, P.M., Potts, S.G., Sandin, L., Sousa, J.P., Storkey, J., Wardle, D.A., Harrison, P.A., 2010. Towards an assessment of multiple ecosystem processes and services via functional traits. Biodiversity and Conservation 19(10): 2873-2893.

de Vries, F.T., Hoffland, E., van Eekeren, N., Brussaard, L., Bloem, J., 2006. Fungal/bacterial ratios in grasslands with contrasting nitrogen management. Soil Biology and Biochemistry 38(8): 2092-2103. 
Denef, K., Six, J., Bossuyt, H., Frey, S.D., Elliott, E.T., Merckx, R., Paustian, K., 2001. Influence of dry-wet cycles on the interrelationship between aggregate, particulate organic matter, and microbial community dynamics. Soil Biology and Biochemistry 33(12-13): 1599-1611.

Domínguez, A., Bedano, J.C., Becker, A.R., Arolfo, R.V., 2014. Organic farming fosters agroecosystem functioning in Argentinian temperate soils: Evidence from litter decomposition and soil fauna. Applied Soil Ecology 83:170-176.

Edwards, C. A. Chapter 6: The Living Soil: Earthworm In: Soil Biology Primer. Tungel, A., Lewandowski, A. HappevonArb, D. (Eds.) 2000. Soil and Water Conservation Society \& NRCS Soil Quality Institute, Ames, IA., USA.

Available at: www.statlab.iastate.edu/survey/SQI/soil_biology_primer.htm [Access date: 05.12.2015]

Eskelinen, A., Stark, S., Männistö, M., 2009. Links between plant community composition, soil organic matter quality and microbial communities in contrasting tundra habitats. Oecologia 161(1): 113-123.

Fageria, N.K., Baligar, V.C., Clark, R.B., 2002. Micronutrients in Crop Production. Advances in Agronomy 7: $185-268$.

FAO, 2005. The importance of soil organic matter: key to drought-resistant soil and sustained food production. FAO Soils Bulletin, No. 80. Food and Agricultural Organization of United Nation, Rome, Italy. pp.11-47

FAO, 2007. Soil Biota and Biodiversity: the "Root" of Sustainable Agriculture. Food and Agricultural Organization of United Nation, Rome, Italy. pp.1-4

Ingham, E. R., 2000. Chapter 3: Bacteria. In: Soil Biology Primer. Tungel, A., Lewandowski, A. HappevonArb, D. (Eds.). Soil and Water Conservation Society \& NRCS Soil Quality Institute, Ames, IA., USA.

Available at: www.statlab.iastate.edu/survey/SQI/soil_biology_primer.htm [Access date: 05.12.2015]

Jenney, H., 2009. Factors of soil formation: A system of quantitative pedology. Dover Publications, New York, USA. 320p.

Jongmans, A.G., Pulleman, M.M., Balabane, M., van Oort, F., Marinissen, J.C.Y., 2003. Soil structure and characteristics of organic matter in two orchards differing in earthworm activity. Applied Soil Ecology 24(3): 219 - 232.

Jürgens, N., Schmiedel, U., Haarmeyer, D.H., Dengler, D., Finckh, M., Goetze, D., Gröngröft, A., Hahn, K., Koulibaly, A., Luther-Mosebach, J., Muche, G., Oldeland, J., Petersen, A., Porembski, S., Rutherford, M.C., Schmidt, M., Sinsin, B., Strohbach, B.J., Thiombiano, A., Wittig, R., Zizka, G., 2012. The BIOTA Biodiversity Observatories in Africa-a staandardized framework for large-scale environmental monitoring. Environmental Monitoring and Assessment 184(2): 655-678.

Kibblewhite, M.G., Ritz, K., Swift, M.J., 2008. Soil health in agricultural systems. Philosophical Transactions of the Royal Society B: Biological Sciences 363: 685-701.

Kramer, C., Gleixner, G., 2008. Soil organic matter in soil depth profiles: Distinct carbon preferences of microbial groups during carbon transformation. Soil Biology and Biochemistry 40(2): 425-433.

Li X., Yin X., Wang Z., Fan W., 2014. Interaction between decomposing litter and soil fauna of the Betula ermanii forest floor of the Changbai Mountains, China. Canadian Journal of Forest Research 44(12): 1507-1514.

Loreau, M., 2010. Linking biodiversity and ecosystems: Towards a unifying ecological theory. Philosophical Transactions of the Royal Society B: Biological Sciences 365: 49-60.

Lubbers, I.M., Brussaard, L., Otten, W., Van Groenigen, J.W., 2011. Earthworm-induced N mineralization in fertilized grassland increases both N20 emission and crop-N uptake. European Journal of Soil Science 62(1): 152 - 161.

Lupwayi, N.Z., Rice, W.A., Clayton, G.W., 1998. Soil microbial diversity and community structure under wheat as influenced by tillage and crop rotations. Soil Biology and Biochemistry 30(13): 1733-1741.

Miyazawa, K., Tsuji, H., Yamagata, M, Nakano, H., Nakamoto, T., 2000. The effect of cropping systems and fallow managements on microarthropod populations. Plant Production Science 5(3): 257-265.

Pankhurst, C.E., Doube, B.M., Gupta, V.V.S.R., 1997. Biological indicators of soil health. CAB International, New York, USA. $451 \mathrm{p}$.

Petchey, O. L., Gaston, K. J., 2006. Functional diversity: back to basics and looking forward. Ecology Letters 9(6): 741758.

Riesenfeld, C. S., Schloss, P. D., Handelsman, J., 2004. Metagenomics: genomic analysis of microbial communities. Annual Review of Genetics 38: 525-552.

Rillig, M.C., Mummey, D.L., 2006. Mycorrhizas and soil structure. New Phytologist 171(1): 41-53.

Ritz, K., 2006. Fungal roles in transport processes in soils. In: Fungi in biogeochemical cycles Gadd, G.M.(Ed.). Cambridge University Press, UK. pp. 51-73.

Ritz, K., Harris, J., Murray, P., 2010. The role of soil biota in soil fertility and quality, and approaches to influencing soil communities to enhance delivery of these functions. Defra project code: SP1601: Sub-Project A of Defra Project SP1601: Soil Functions, Quality and Degradation - Studies in Support of the Implementation of Soil Policy. Cranfield University and Rothamsted Research, UK, 34 pp.

Ritz, K., McHugh, M., Harris, J.A., 2004. Biological diversity and function in soils: contemporary perspectives and implications in relation to the formulation of effective indicators. In: Agricultural soil erosion and soil biodiversity: Developing indicators for policy analyses. Francaviglia, R. (Ed.), OECD, Paris, France. pp. 563-572.

Six, J., Bossuyt, H., Degryze, S., Denef, K., 2004. A history of research on the link between (micro) aggregates, soil biota, and soil organic matter dynamics. Soil and Tillage Research 79(1): 7-31. 
Smith, R. G., McSwiney, C. P., Grandy, A. S., Suwanwaree, P., Snider, R. M., Robertson, G. P., 2008. Diversity and abundance of earthworms across an agricultural land-use intensity gradient. Soil Tillage Research 100(1-2): 8388.

Song X., Song Y., Sun T., Zhang W., Zhou Q., 2004. Bio-indicating function of soil protozoa to environmental pollution. Chinese Journal of Applied Ecology 15(10): 1979-1982. [in Chinese].

Swift, M.J., Heal, O.W., Anderson, J.M., 1979. Decomposition in terrestrial ecosystems. University of California Press, Berkeley \& Los Angeles, USA. 372p.

Tisdall, J.M., Oades, J.M., 1982. Organic matter and water stable aggregates in soils. Journal of Soil Science 33(2): 141163.

UNEP, 1995. Global biodiversity assessment. United Nations Environment Program (UNEP) Cambridge University Press, UK. 17p.

UNEP, 2006. Global Environment Outlook 3: Land degradation - Africa.

Available at: http://www.grida.no/geo/geo3/english/149.htm [Access date: 25.08.2006]

Usman, S., 2013. Understanding soils: Environment and properties under agricultural conditions. Publish America, Baltimore, USA. 151p.

Wall, D.H., Adams, G., Parsons, A.N., 2001. Soil Biodiversity. In: Global biodiversity in a changing environment: Scenarios for the 21st century. Chapin III, F.S., Sala, O.E., Huber-Sannwald, E. (Eds.), Springer-Verlag, New York, USA. pp. 47-82.

Wang, M.C, Liu, Y.H., Wang, Q., Gong, M., Hua, X.M., Pang, Y.J., Hu, S., Yang, Y.H., 2008. Impacts of methamidophos on the biochemical, catabolic and genetic characteristics of soil microbial communities. Soil Biology and Biochemistry 40(3): 778-788.

Yeates, W.G., Coleman, D.C., 1982. Role of nematodes in decomposition. In: Nematodes in soil ecosystem. Freckman, D.W. (Ed.). University of Texas Press. Austin, USA. pp. 50-80. 